\title{
The Motivations and Barriers of Teachers' Professional Development Activities during the Movement Control Order (MCO) - A Preliminary Insight
}

\author{
Asraf Hadzwan Ahmad Safian and Anidah Robani \\ Institute of Technology Management and Entrepreneurship, \\ Universiti Teknikal Malaysia Melaka (UTeM) \\ https://orcid.org/0000-0003-2579-9958 \\ https://orcid.org/0000-0001-6268-7758 \\ Muliati Sedek \\ Centre For Language Learning, \\ Universiti Teknikal Malaysia Melaka (UTeM) \\ https://orcid.org/0000-0003-2613-6451
}

\begin{abstract}
Due to the severe acute respiratory syndrome coronavirus 2 (SARS-COV-2) or COVID-19 pandemic, the education sector in Malaysia opted for the practice of online communication as a new norm. However, even during the pandemic, teachers in Malaysia are obliged to involve with professional development (henceforth, PD) activities for at least 42 hours annually. This article is prepared from a preliminary study to report the motivating factors and barriers on teachers' PD activities during Malaysia's Movement Control Order (henceforth, MCO). Also, this article studied the prevalence and trend of the teachers' online communication during the period. A survey was conducted as a pilot study on 35 teachers from Sri Laksamana Primary School (henceforth, SLPS) in Melaka. The data gained were analysed descriptively using the SPSS software. In general, the results indicate that teachers are motivated to involve with online PD activities by getting rewarded with annual performance evaluation marks, which is beneficial for their career mileage. Next, the most significant barrier for their online PD is time limitation due to other workloads. In conclusion, even though the teachers are well-accepting online PD activities, teachers should be given a higher portion of evaluation marks regarding their annual PD involvement than the current five per cent portion. Next, the school's administrators should act on teachers' work distribution issues that became the main challenge for effective online $\mathrm{PD}$, thus creating a favourable working ecosystem.
\end{abstract}


Keywords: online communication; telecommuting; pandemic; motivations; barriers

\section{Introduction}

This pilot study aims to discover teachers' motivations and barriers for their online PD sessions during the Movement Control Order (MCO). In Malaysia, the MCO was enforced starting on the 18th of March, 2020, due to the quick spreading of COVID-19 (Shaha et al., 2020). During the MCO, the social and physical limitations prevented more spreading of COVID-19 and have transformed formal programmes such as courses, workshops, or any official gatherings to be done online. Even though the government sectors in Malaysia were trying to avoid the virus from spreading, public schools were found to function as usual. Teachers and schools staff were opted to work from home, practising telecommuting using internet-based technologies.

As far as the PD process is concerned, teachers should proceed regularly (Zakiyuddin, 2019) even during the MCO as Malaysian teachers must fulfil their PD obligations and record their participation in the Continuous Professional Development Credit Point System (MyPPB). The teachers must achieve at least 42 credit points annually, equivalent to 42 hours of PD participation. The PD activities can be in the form of activities listed in Table 1 and are usually carried out by in-house training programmes in schools where teachers are gathered to learn about new information or skills (Jamil et al., 2011). Therefore, even by telecommuting using internet-based technologies, PD is an important activity that teachers should regularly do as an obligation to share new knowledge with their colleagues, be trained, and be constantly updated with the latest information and skills, including during the pandemic period.

This pilot study also tested the questionnaire items and validated the instrument's reliability for the planned actual research. By questioning the teachers' motivating factors and barriers during their online PD sessions and the prevalence and trend for their online PD activities, their readiness to do so during the MCO is exposed.

\section{Literature Review}

However, there are other ways for teachers to learn even during the $\mathrm{MCO}$ in Malaysia. Teachers can continue to learn during the pandemic as they are provided with opportunities to learn more about learning through digital methods (Pokhrel \& Chhetri, 2021). Since they need to adapt to online learning (Konig et al., 2020), education administrators also are recommended to provide proper and safe guidelines for teachers to continually learn through the pandemic (Muhayimana, 2020).

Facing changes in teachers' working environment, from physical attendance to online communication, can be stimulated with proper motivations such as support and influence by people around (Savvidou, 2020) and spending less on commuting expenses (Fadzilah et al., 2021). Motivations to work from home occur when the proper distribution of workloads is done among employees, having fewer networking issues, having government support with effective 
employment act that covers the safety of working from home, and the employees' intrinsic motivation to be fulfilled by themselves (Marimuthu \& Vasudevan, 2020). Teachers also require support systems in ICT literacy training (Khan \& Kazmi, 2020) and the freedom to choose PD activities that suit their interests (Moekwa, 2020).

Meanwhile, many researchers reported that teachers faced obstacles such as limited ICT literacy (Alea et al., 2020), juggling personal responsibilities, and being unable to properly manage time while working from home (Marimuthu \& Vasudevan, 2020). Also, previous research showed that network connectivity issues (Savvidou, 2020), financial issues, other job scope conflicts (Badri et al., 2016), ineffective online PD design (Quinn et al., 2020), and unsatisfactory telecommuting using technologies (Alvarez, 2020) are among the barriers too.

As most teachers in Malaysia were reported to practise limited use of technology such as word processing applications, spreadsheets, presentations, and email applications (Singh \& Chan, 2014), this study is conducted to know more about the motivations and barriers on teachers' PD activities that were done online during the MCO. Teachers in Malaysia can join any of the listed activities below as their PD involvement, and these activities can be credited into the MyPPB system:

Table 1: Examples of PD activities acknowledged by the Malaysian Ministry of Education (MOE) (Malaysian Ministry of Education, 2019)

\begin{tabular}{|c|c|c|}
\hline No. & PD Program & Examples of Activities \\
\hline 1. & Training & $\begin{array}{c}\text { Courses, seminars, convocations, workshops, } \\
\text { forums, symposiums, colloquium, official } \\
\text { trips, any form of formal and semi-formal } \\
\text { meetings }\end{array}$ \\
\hline 2. & Learning & $\begin{array}{c}\text { Peers learning community (PLC), executive } \\
\text { talks, monthly assembly, celebration / festive } \\
\text { programs, mentor-mentee meetings, } \\
\text { presentations, career counselling sessions }\end{array}$ \\
\hline 3. & Self-learning & $\begin{array}{c}\text { Online portal sessions, reading book / journal } \\
\text { / report / research readings, news }\end{array}$ \\
\hline
\end{tabular}

In conclusion, motivating factors and barriers exist for teachers who work from home using online-based communication technologies. Therefore this pilot study investigated the motivations and barriers for teachers from the selected school to use technologies in fulfilling their annual PD obligations, specifically during the MCO. Also, studying how they perceived online communication during that time examining their readiness to work remotely during the pandemic. This research also gave details on what can be suggested to improve the situation or practices with online PD among teachers in Malaysia. This literature review section in this article is followed by research methods, findings, discussions, conclusion, and references sections. 


\section{Methods}

A quantitative approach was taken to investigate the issues stated. A questionnaire was designed to probe all the research questions. Then the printed questionnaire was distributed to the samples. The samples are teachers from Sri Laksamana Primary School (henceforth, SLPS), a public primary school located in the district of Alor Gajah in Melaka.

This pilot study was done in person rather than online because the samples helped provide direct feedback regarding any improvements that could be made to the questionnaire. The data collected are analysed descriptively in Social Packages for the Social Science (SPSS) Statistics software. The frequency, standard deviation, and interpretation will be shown in tables to show precise numbers and charts to be further elaborated.

\subsection{Participants}

From the total of 55 female $(85.93 \%)$ and nine male teachers $(14.07 \%)(\mathrm{N}=64)$ in SLPS, 35 samples $(n=35)$ were selected randomly to answer the questionnaire as pilot study samples were recommended to be more than thirty samples (Bujang et al., 2018). The samples' specialisation and backgrounds are varied, but they are all obliged to achieve $42 \mathrm{MyPPB}$ credit points annually.

\subsection{Procedure}

Protocols and permission for this research were approved by the State Education Department (SED) of Melaka and the Ministry of Education (MOE) of Malaysia. Permission letters by both parties were presented during the survey containing the basic details of the research. The questionnaire's responses were noted, including typing errors, ease of answering questions, and time for the questionnaire completion. All participants received a token of appreciation in the form of a custom-made SLPS's blazer button badge.

\section{Research Instruments}

All data from this pilot study were collected using a validated printed questionnaire. The pilot study will benefit the actual research by helping the researcher to understand the samples' feedback, thus providing the researcher's readiness for the actual research (Malmqvist et al., 2019) while answering the questionnaire. The questionnaire is prepared in five parts with 44 questions, probing different information for this research. The first section recorded respondents' basic information with six questions. Then another section investigated the samples' motivating factors for their online PD activities. The third section consisted of eight questions that probed the samples' barriers to doing so. Section D and E of the questionnaire, respectively, consisted of 18 and seven questions. The sections investigated the samples' experience acquiring their prevalence and trend during the activities, while the last section asked the samples' suggestions on what can be improved to help them be involved with online PD activities.

The Likert Scale was used in parts B, C, D and E of this questionnaire. There are two parts of four points and five points scale, respectively. Different scales are used because some questionnaire sections require only an agreement (strongly 
agree and agree) and disagreement ideas only (strongly disagree and disagree), depending on the section's objective (Joshi et al., 2015).

\subsection{Data Analysis}

Data analysis procedures were performed using IBM SPSS Statistics version 26. Descriptive analyses were conducted using the software. The frequencies and means of the variables were analysed to support interpretations related to the research questions.

\section{Findings}

\subsection{Demographic Profile}

The samples for this pilot study are academic teachers, with six and one of them respectively serving in the SLPS Special Education Classes and Preschool Class. The administrators of SLPS are not involved with this pilot study. Three of the respondents are male since only $14.07 \%$ of the teachers in the school are male. They mainly were born before the internet was provided domestically in Malaysia (1970 - 1979: 54.30\%), with most of them not living in a city area $(80.00 \%)$. The most popular internet connectivity type among them is by WIFI connection $(57.14 \%)$. The data will help to further elaborate the prevalence and trend of teachers' online PD during the MCO. Table 2 shows the exact results for these 35 pilot study respondents.

Table 2: Respondents' Demographic Profile

\begin{tabular}{|l|l|l|l|}
\hline \multicolumn{2}{|c|}{} & $\begin{array}{l}\text { Frequency } \\
(\mathbf{n}=\mathbf{3 5})\end{array}$ & $\begin{array}{l}\text { Valid Percentage } \\
(\mathbf{\%})\end{array}$ \\
\hline \multirow{4}{*}{ Teachers' Category } & Academic Teachers & 28 & 80.00 \\
\cline { 2 - 4 } & Special Education Teachers & 6 & 17.10 \\
\cline { 2 - 4 } & Preschool Teachers & 1 & 2.90 \\
\hline \multirow{4}{*}{ Gender } & Male & 3 & 8.60 \\
\cline { 2 - 4 } & Female & 32 & 91.40 \\
\hline \multirow{3}{*}{ Rirth Year } & 1990 and above & 3 & 8.60 \\
\cline { 2 - 4 } & $1980-1989$ & 13 & 37.10 \\
\cline { 2 - 4 } & $1970-1979$ & 19 & 54.30 \\
\hline \multirow{3}{*}{$\begin{array}{l}\text { Primary Internet } \\
\text { Connectivity }\end{array}$} & City & 7 & 20.00 \\
\cline { 2 - 4 } & Rural & 28 & 80.00 \\
\cline { 2 - 4 } & Lireless Fidelity (WIFI) & 20 & 57.14 \\
\cline { 2 - 4 } & Mobile Network & 1 & 2.86 \\
\cline { 2 - 4 } & Hotspot Tethering & 12 & 34.29 \\
\hline
\end{tabular}

\subsection{Motivations for Participating in Online PD Activities}

Section B for this questionnaire probed the samples regarding their motivating factors for online PD participation using a 5-point Likert Scale. For this section, as shown in Table 3, the values are interpreted as 1.0 - $1.8=$ Strongly Disagree; 1.9 - 2.7 = Disagree; $2.8-3.6=$ Neutral; $3.7-4.5=$ Agree and $4.6-5.4=$ Strongly Agree . Cronbach's alpha score for this section is 0.626 . There are no Strongly Disagree or Disagree interpreted means in this section. However, the means between factors still differ from one another. 
The highest mean of motivating factor is reward in the form of Annual Achievement Evaluation Report (AAER) $(M=4.3, S D=5.22968)$, followed by feeling responsible to achieve the minimum MyPPB credit points $(M=4.1, S D=$ $0.60112)$, the interest of involving with the PD activities $(M=3.9, S D=0.50709)$, and support from colleagues $(M=3.8, S D=0.68966)$ which are all interpreted as agree. The respondents are responding neutrally on other factors which are support from their superiors $(M=3.4, S D=0.84714)$ and feeling motivated by having gadgets given by the government $(M=3.0, S D=1.04278)$.

Table 3: Responses Regarding Samples' Motivations during their Online PD Activities from the 18th of March 2020 to the 31st of December 2020.

\begin{tabular}{|c|c|c|c|c|}
\hline Section & Item & $\begin{array}{c}\text { Mean } \\
(\mathrm{M}) \\
(\mathrm{n}=35)\end{array}$ & $\begin{array}{l}\text { Standard } \\
\text { Deviation } \\
\text { (SD) }\end{array}$ & $\begin{array}{c}\text { Verbal } \\
\text { Interpretation }\end{array}$ \\
\hline D27 & $\begin{array}{c}\text { Interest in professional } \\
\text { development activities involved. }\end{array}$ & 3.9 & .50709 & Agree \\
\hline D28 & $\begin{array}{c}\text { Feeling responsible to achieve } 42 \\
\text { MyPPB credit points. }\end{array}$ & 4.1 & .60112 & Agree \\
\hline D29 & $\begin{array}{l}\text { Gadgets given by the } \\
\text { government. }\end{array}$ & 3.0 & 1.04278 & Neutral \\
\hline D30 & $\begin{array}{c}\text { Support from superiors } \\
\text { (SCHOOL ADMINISTRATORS / } \\
\text { DEO / SED / MOE). }\end{array}$ & 3.4 & .84714 & Neutral \\
\hline D31 & Support from colleagues. & 3.8 & .68966 & Agree \\
\hline D32 & $\begin{array}{c}\text { Reward in the form of Annual } \\
\text { Achievement Evaluation Report } \\
\text { marks. }\end{array}$ & 4.3 & 5.22968 & Agree \\
\hline
\end{tabular}

\subsection{Barriers for Online Professional Development Participation.}

Another 5-point Likert Scale was used in the next section, recording the barriers for online PD activities joined by the samples. This section, as shown in Table 4, interpreted the mean values as $1.0-1.8=$ Strongly Disagree; $1.9-2.7=$ Disagree; $2.8-3.6=$ Neutral; $3.7-4.5=$ Agree ; and 4.6 - 5.4 = Strongly Agree .

The highest mean of barriers is time limitation due to other primary workloads $(M=4.0, S D=0.89066)$, followed by family responsibilities $(M=3.9, S D=$ 1.02244), and limited internet coverage $(M=3.7, S D=1.02244)$. All of the mentioned barriers were interpreted verbally as agree. There are four barriers where the respondents respond and interpret as neutral. They are poorly working gadgets used during the PD sessions $(M=3.5, S D=1.05169)$, limited internet quota $(M=3.7, S D=1.09391)$, limited ICT literacy $(M=3.4, S D=$ $0.94824)$, and lack of support from their superiors $(M=3.0, S D=0.70651)$. However, there is one questionnaire item that is interpreted as disagree: lack of support from colleagues $(M=2.6, S D=0.55761)$. The Cronbach's alpha for this section is 0.764 . 
Table 4: Responses Regarding Samples' Barriers during their Online PD Activities from the 18th of March 2020 to the 31st of December 2020.

\begin{tabular}{|c|c|c|c|c|}
\hline Section & Item & $\begin{array}{c}\text { Mean } \\
(\mathbf{M}) \\
(\mathbf{n = 3 5 )}\end{array}$ & $\begin{array}{c}\text { Standard } \\
\text { Deviation } \\
(\mathbf{S D})\end{array}$ & $\begin{array}{c}\text { Verbal } \\
\text { Interpretation }\end{array}$ \\
\hline E33 & Limited internet coverage. & 3.7 & 1.02244 & Agree \\
\hline E34 & Limited internet quota. & 3.5 & 1.09391 & Neutral \\
\hline E35 & Poorly working gadget/device. & 3.5 & 1.05169 & Neutral \\
\hline E36 & Limited ICT literacy. & 3.4 & .94824 & Neutral \\
\hline E37 & $\begin{array}{c}\text { Time limitation due to other } \\
\text { primary workloads. }\end{array}$ & 4.0 & .89066 & Agree \\
\hline E38 & Family responsibilities. & 3.9 & 1.02244 & Agree \\
\hline E39 & $\begin{array}{c}\text { Lack of support from the } \\
\text { superiors (school administrators } \\
\text { / DEO / SED / MOE). }\end{array}$ & 3.0 & .70651 & Neutral \\
\hline E40 & Lack of support from colleagues. & 2.6 & .55761 & Disagree \\
\hline
\end{tabular}

\subsection{Prevalence and trend: Activities Joined for Online PD}

As mentioned in Table 1, there are three types of PD activities recognised by the MOE. For this section, respondents can choose more than one activity they have joined online during the MCO. There are 19 types of activities joined by the samples from all three types of PD activities listed. In Table 5, the respondents' frequency of each activity is entered, with the valid percentage representing each activity's portion among all of the joined activities recorded.

The most frequent activity joined by the respondents with 26 respondents is knowledge sharing which can be in the form of PLC, formal or informal sessions. An equal number of participants is also shown for the Digital Education Learning Initiative Malaysia (DeLIMA) self-learning portal. Online assembly and briefing also are reported to be commonly joined by 23 respondents. The sessions are usually conducted for a particular group of teachers, for example, for a committee, or it can be performed for all SKSL teachers.

The listed activities without participation by any samples are convention, symposium, colloquium, official trip, field trip, mentor-mentee meetings, paperwork presenter, and giving lectures.

Table 5: PD Activities Joined by the Respondents from the 18th of March 2020 to the 31st of December 2020

\begin{tabular}{|c|c|c|c|}
\hline $\begin{array}{c}\text { Activities } \\
\text { Category }\end{array}$ & Activity & Frequency & $\begin{array}{c}\text { Valid Percentage } \\
\mathbf{( \% )}\end{array}$ \\
\hline Training & Courses & 16 & 45.70 \\
\cline { 2 - 4 } & Seminar & 17 & 48.60 \\
\cline { 2 - 4 } & Convention & 0 & 0.00 \\
\cline { 2 - 4 } & Workshop & 14 & 40.00 \\
\cline { 2 - 4 } & Forum & 7 & 20.00 \\
\cline { 2 - 4 } & Symposium & 0 & 0.00 \\
\cline { 2 - 4 } & Colloquium & 0 & 0.00 \\
\cline { 2 - 4 } & Official Trip & 0 & 0.00 \\
\cline { 2 - 4 } & Field Trip & & 0.00 \\
\hline
\end{tabular}




\begin{tabular}{|c|c|c|c|}
\hline & Counselling Clinic & 1 & 2.90 \\
\hline \multirow[t]{12}{*}{ Learning } & Knowledge Sharing & 26 & 74.30 \\
\hline & Talk & 19 & 54.30 \\
\hline & Assembly and Briefing & 23 & 65.70 \\
\hline & Celebration Programme & 7 & 20.00 \\
\hline & Launching Ceremony & 9 & 25.70 \\
\hline & Mentor-mentee Meeting & 0 & 0.00 \\
\hline & Discussion & 18 & 51.40 \\
\hline & $\begin{array}{c}\text { Paperwork Presentation } \\
\text { Audience }\end{array}$ & 0 & 0.00 \\
\hline & Paperwork Presenter & 0 & 0.00 \\
\hline & Organisational Counselling & 2 & 5.70 \\
\hline & Attending Lectures & 14 & 40.00 \\
\hline & Giving Lectures & 0 & 0.00 \\
\hline \multirow[t]{6}{*}{ Self-Learning } & Use EPSA Learning Platform & 7 & 20.00 \\
\hline & $\begin{array}{l}\text { Use EP-MABLS Learning } \\
\text { Platform }\end{array}$ & 10 & 28.6 \\
\hline & Use DeLIMA Learning Platform & 26 & 74.30 \\
\hline & $\begin{array}{c}\text { Use Other Online Learning } \\
\text { Portal }\end{array}$ & 14 & 40.00 \\
\hline & Read Printed Materials & 17 & 48.60 \\
\hline & Read Digital Materials & 21 & 60.00 \\
\hline
\end{tabular}

The samples' experiences related to their online PD activities are recorded in the next part of this questionnaire section. Among all of the samples, most of them showed positive responses for items related to their experience regarding online PD. Most of the respondents $(91.40 \%)$ used their selected gadgets for online PD before the MCO. They also managed to fulfil their required MyPPB credit points during the $\mathrm{MCO}(97.10 \%)$, and only a small number $(17.10 \%)$ did not manage to finish at least one online PD activity due to any barrier.

Table 6: Responses Regarding Samples' Experiences during their Online PD Activities from the 18th of March 2020 to the 31st of December 2020

\begin{tabular}{|c|c|c|c|}
\hline Item & & $\begin{array}{c}\text { Frequency } \\
(\mathbf{n = 3 5 )}\end{array}$ & $\begin{array}{c}\text { Valid Percentage } \\
(\mathbf{\%})\end{array}$ \\
\hline $\begin{array}{c}\text { Have you ever used the gadget(s) you } \\
\text { have chosen for any PD activities before } \\
\text { the MCO? }\end{array}$ & Yes & 32 & 91.43 \\
\cline { 2 - 4 } & No & 3 & 8.57 \\
\hline $\begin{array}{c}\text { Did you manage to fulfil the required } \\
\text { credit points of PD during the MCO } \\
(18 / 3 / 2020-31 / 12 / 2020) ?\end{array}$ & Yes & 34 & 97.14 \\
\cline { 2 - 4 } & No & 1 & 2.86 \\
\hline $\begin{array}{c}\text { Have you ever not completed any PD } \\
\text { activity during the MCO (18/3/2020 - } \\
31 / 12 / 2020) \text { due to any barriers? }\end{array}$ & Yes & 6 & 17.14 \\
\cline { 2 - 4 } & No & 29 & 82.86 \\
\hline
\end{tabular}

The following part of this section probed the respondents using a 4-point Likert scale. The mean and standard deviation (SD) are indicators of determining the respondents' responses regarding the prevalence and trends of their online PD (Table 8). Throughout this result section, the SD pertains to how the data were spread out. Next, for this section with a 4-point Likert scale, the values are 
verbally interpreted as $1.00-1.75=$ Strongly Disagree; $1.76-2.51=$ Disagree; 2.52 $3.27=$ Agree $;$ and $3.28-4.03=$ Strongly Agree .

Table 8 shows the responses of samples regarding their trend of online PD activities during the MCO. The Cronbach alpha's score for this section is 0.833 . The samples managed to improve with using teleconferencing applications $(M=3.43, S D=0.50)$ during the MCO. Even though they are already familiar with using digital gadgets even before the pandemic $(M=3.14, S D=0.60)$, they also strongly agree that their skills in using digital devices improved during the period $(M=3.43, S D=0.50)$. They also accepted the trend of online PD well, admitting that, rather than attending PD activities physically, online PD activities are easier to fulfil their minimum MyPPB credit points $(M=3.37$, $S D=0.49)$, easier to learn $(M=2.80, S D=0.58)$, and more comfortable $(M=3.26$, $S D=0.56)$. They are also ready to participate with online PD $(M=3.09, S D=0.61)$ without being forced to $(M=3.14, S D=0.55)$ and prepared to learn new ICT-based skills that are related to online PD $(M=3.26, S D=0.56)$. Despite being interpreted verbally as agree, with a relatively low value of mean $(M=2.54, S D=0.70)$, the samples perceived their superiors gave enough ICT-related skills training to them, which will elaborate more later barriers and motivating factors as variables.

Table 7: Responses Regarding Samples' Experiences during their Online PD Activities from the 18th of March 2020 to the 31st of December 2020 and How they Perceive Technology

\begin{tabular}{|c|c|c|c|c|}
\hline Section & Item & $\begin{array}{c}\text { Mean } \\
(\mathrm{M}) \\
(\mathrm{n}=35)\end{array}$ & $\begin{array}{l}\text { Standard } \\
\text { Deviation } \\
\text { (SD) }\end{array}$ & $\begin{array}{c}\text { Verbal } \\
\text { Interpretation }\end{array}$ \\
\hline C15 & $\begin{array}{c}\text { You were capable of using your } \\
\text { choice of gadget(s) above before } \\
\text { the MCO. }\end{array}$ & 3.14 & 0.60112 & Agree \\
\hline $\mathrm{C} 16$ & $\begin{array}{c}\text { You were already capable of using } \\
\text { teleconferencing applications such } \\
\text { as Google Meet, Zoom, Webex, } \\
\text { etc., before the MCO. }\end{array}$ & 2.14 & 0.77242 & Not Agree \\
\hline C17 & $\begin{array}{l}\text { You have increased your skills of } \\
\text { using digital gadget(s) that you } \\
\text { have chosen above during the } \\
\text { MCO }(18 / 3 / 2020-31 / 12 / 2020)\end{array}$ & 3.43 & 0.50210 & Strongly agree \\
\hline $\mathrm{C} 18$ & $\begin{array}{l}\text { You have increased your skills of } \\
\text { using teleconferencing applications } \\
\text { such as Google Meet, Zoom, } \\
\text { Webex, etc., during the MCO } \\
(18 / 3 / 2020-31 / 12 / 2020)\end{array}$ & 3.43 & 0.50210 & Strongly agree \\
\hline C19 & $\begin{array}{l}\text { Online professional development } \\
\text { is easier to fulfil the required credit } \\
\text { points rather than in person. }\end{array}$ & 3.37 & 0.49024 & Strongly agree \\
\hline $\mathrm{C} 20$ & $\begin{array}{l}\text { I can learn a content of a } \\
\text { professional development session } \\
\text { easier by online rather than in } \\
\text { person. }\end{array}$ & 2.80 & 0.58410 & Agree \\
\hline $\mathrm{C} 21$ & I am ready to participate in online & 3.09 & 0.61220 & Agree \\
\hline
\end{tabular}




\begin{tabular}{|c|c|c|c|c|}
\hline & $\begin{array}{c}\text { professional development activities } \\
\text { during the early stage of MCO } \\
(18 / 3 / 2020-31 / 12 / 2020) .\end{array}$ & A & Agree \\
\hline C22 & $\begin{array}{c}\text { I am ready to learn new skills } \\
\text { related to ICT during the early } \\
\text { stage of MCO }(18 / 3 / 2020- \\
31 / 12 / 2020) .\end{array}$ & 3.14 & 0.49366 & Agree \\
\hline C23 & $\begin{array}{c}\text { I agree that online professional } \\
\text { development is done continuously } \\
\text { rather than face-to-face. }\end{array}$ & 3.23 & 0.64561 & Agree \\
\hline C24 & $\begin{array}{c}\text { I am more comfortable to involve } \\
\text { with online professional } \\
\text { development rather than in person. }\end{array}$ & 3.26 & 0.56061 & Agree \\
\hline C25 & $\begin{array}{c}\text { My online professional } \\
\text { development involvements are } \\
\text { done without being forced to. }\end{array}$ & 3.14 & 0.55002 & Agree \\
\hline C26 & $\begin{array}{c}\text { School / DEO / SED / MOE gave } \\
\text { me enough training to be skilful in } \\
\text { using internet-based applications } \\
\text { for professional development. }\end{array}$ & 2.54 & 0.70054 & \\
\hline
\end{tabular}

\subsection{Suggestions for Improving Online PD}

The last section of this questionnaire probed the respondents using another 4point Likert scale, similar to section $C$, as shown in Table 9. The mean values are interpreted as $1.00-1.75=$ Strongly Disagree; $1.76-2.51=$ Disagree; $2.52-3.27=$ Agree; and $3.28-4.03=$ Strongly Agree. This section obtains the samples' suggestions on improvements for their online PD activities and with a recorded Cronbach alpha score of 0.839 . The purpose of this section was to propose recommendations based on the ideas given by the teachers who went through the whole process themselves so that the ideas will be more realistic and relevant.

All responses are interpreted as agree in this section; however, the values of mean in each suggestion are different. The suggestion with highest value of mean is ICT literacy-related training programmes provided by the superiors $(M$ $=3.23, S D=0.54695)$, followed by special package from the network provider to buy gadgets $(M=3.17, S D=0.98476)$, government monetary incentives for gadget purchasing $(M=3.15, S D=1.04830)$, special packages from the network provider to purchase internet data $(M=3.14, S D=0.91210)$, government monetary incentives for internet data purchasing $(M=3.09, S D=0.96508)$, more user-friendly self-learn online platforms $(M=2.97, S D=0.66358)$, and more user-friendly teleconferencing applications $(M=2.94, S D=0.68354)$.

Table 8: Responses Regarding Respondents' Suggestions that can Improve their Online PD Activities.

\begin{tabular}{|c|c|c|c|c|}
\hline Section & Item & $\begin{array}{c}\text { Mean } \\
(\mathbf{M}) \\
(\mathbf{n = 3 5 )}\end{array}$ & $\begin{array}{c}\text { Standard } \\
\text { Deviation } \\
\text { (SD) }\end{array}$ & $\begin{array}{c}\text { Verbal } \\
\text { Interpretation }\end{array}$ \\
\hline F41 & $\begin{array}{l}\text { Self-learn platforms that are } \\
\text { easier to use rather than the } \\
\text { current platforms (DeLIMA, }\end{array}$ & 2.97 & .66358 & Agree \\
\hline
\end{tabular}




\begin{tabular}{|c|c|c|c|c|}
\hline & EPSA or EP-MABLS. & & & \\
\hline F42 & $\begin{array}{l}\text { Meeting application that is } \\
\text { easier to use rather than the } \\
\text { current applications (Zoom, } \\
\text { Google Meet, or Cisco Webex) }\end{array}$ & 2.94 & .68354 & Agree \\
\hline F43 & $\begin{array}{l}\text { Schools / DEO / SED / MOE } \\
\text { can organise more training } \\
\text { programmes regarding gadgets } \\
\text { and online applications learning. }\end{array}$ & 3.23 & .54695 & Agree \\
\hline F44 & $\begin{array}{l}\text { Monetary incentive from the } \\
\text { government for gadget } \\
\text { purchasing. }\end{array}$ & 3.15 & 1.04830 & Agree \\
\hline F45 & $\begin{array}{l}\text { Monetary incentive from the } \\
\text { government for internet data } \\
\text { purchasing. }\end{array}$ & 3.09 & 96508 & Agree \\
\hline F46 & $\begin{array}{l}\text { Special packages from the } \\
\text { network provider for gadget } \\
\text { purchasing. }\end{array}$ & 3.17 & .98476 & Agree \\
\hline F47 & $\begin{array}{l}\text { Special packages from the } \\
\text { network provider for internet } \\
\text { data purchasing. }\end{array}$ & 3.14 & .91210 & Agree \\
\hline
\end{tabular}

\section{Discussion}

\subsection{Motivations for Online PD Activities}

The result indicates that the samples were highly motivated by getting rewarded in Annual Achievement Evaluation Report (AAER) marks. Teachers in Malaysian Government Schools have the freedom in preparing their Annual Work Target (AWT), a document used to generate AAER marks. By May and October every year, they can write any scope of work within their expertise and responsibilities that they want to achieve in the AWT. The AWT then will be verified and evaluated into AAER marks by their superiors. Annual AAER marks can be used to expand teachers' careers. However, the AAER marks from teachers' annual PD participation can only be rewarded by five per cent (Malaysian Ministry of Education, 2021). It is a relatively small amount for a motivating factor related to teachers' process of improving their practices.

With the smallest number of means recorded among all listed motivating factors, the samples also perceived neutrally that the government's free gadgets are motivating. This indicates that the teachers were not encouraged by free gadgets given to them to practise online-based activities. In SLPS, the teachers were given free smartphones and tablets in 2017 and 2018, respectively, by the Malaysian MOE. However, the devices' specifications were lower than the current standard requirement for multipurpose work use. Therefore, the Ministry should thoroughly plan any further plans to get teachers equipped with gadgets as motivation.

\subsection{Barriers for Online PD Activities}

Teachers in Malaysia are burdened with teaching workloads and other additional duties, thus resulting in time strain (Kamarudin \& Taat, 2020; Hizan \& Rodzalan, 2020). Therefore, it is evident that time limitations due to other 
workloads are the main barrier for the samples to be effectively involved with online PD. This indicates that teachers struggled to get used to working remotely during the pandemic period. In addition, the second-highest barrier recorded in this section is 'Family responsibilities', which is in line with teachers' time strain to work from home. The result can be concluded that school administrators should be aware of teachers' teaching workloads and additional duties. The issue should be managed with proper guidelines of work distribution, creating a less stressful working environment. Also, the MOE should consider employing more teaching assistant personnel in schools too.

The samples perceived neutrally to other barriers, including lack of support from the superiors and expressed disagreement to lack of colleagues' support, as barriers to participating with online PD activities. This indicates two possibilities; either they do not perceive the absence of assistance from colleagues as a barrier, or they do have support from their colleagues. The second possibility can be correlated with points stated in 5.1 and the paragraph noted above, proposing that colleagues support is also a motivating factor for the samples, thus becoming a part of a positive working environment. Therefore, it is worth noting that a productive working ecosystem is essential to workers' productivity, and administrators should always play their role in maintaining it.

\subsection{Prevalence and Trend}

As many as 54.30 per cent of the samples are digital nomads (Kincl \& Strach, 2018) who adapted themselves in blending well with technologies for work. Next, even though 80.00 per cent of the samples live in a rural residential area, that did not prevent them from getting online since all the samples recorded to be connected to the internet, with $20(57.14 \%)$ of them using wireless fidelity (WIFI) connection. This result indicates that all the respondents can be involved with online PD and not affected by their location of living and which generation they are.

Based on Table 5, all activities, except for 'Reading printed materials', were adapted to be done online. As 'Knowledge sharing' and 'Using DeLIMA learning platform' recorded the same highest frequencies, both are due to different reasons. 'Knowledge sharing' can be widely translated into activities such as formal (compulsory) and informal (self-initiated) PLCs or even small group teleconferencing. As long as the discussion topics are beneficial for their profession, the samples are allowed to key in the details to be acknowledged by their superiors through the MyPPB portal. Therefore, the frequencies recorded show that the samples were actively involved with mandatory and self-initiated online PD activities during the MCO. Also, some activities which used to be done by physical attendance can be adapted into online-based methods.

In this research, as shown in Table 7 , we can conclude that the samples improved themselves by using teleconferencing applications and devices for online PD during the MCO. Also, they perceive online PD activities and carry them out well to achieve their requirement. However, a relatively low mean $(M=2.54)$ is recorded for agreeing that their superiors gave them enough training 
in ICT-related skills. Therefore, the teachers may initiate self-learning or carry out PLCs to improve their ICT-related skills during the MCO.

\section{Conclusion}

This preliminary study gave early insights regarding the actual research that will explore the readiness of a larger group of teachers with online PD in Malaysia. In conclusion, the results from this study have provided the readers with an early understanding of what teachers face during the early stage of this pandemic period. First, as teachers value getting rewarded for their participation in PD activities, it is suggested that Malaysian school administrators increase the amount of AAER marks given to teachers rather than only five per cent of the maximum marks currently allocated. This might promote a more positive working ecosystem where teachers are appreciated for their learning efforts. Further studies regarding the correlation between AAER mark portion and teachers' work satisfaction are recommended. Second, further actions should be taken regarding Malaysian teachers' workload and work distribution issues as supported by previous research in Section 6.2. Teachers' assistant positions and more management employees are recommended to be placed in schools to reduce teachers' educational management workloads. Third, despite having some struggles, the teachers involved perceived well on adapting with online PD based on their participation and activities recorded. This can be correlated to the suggestions section, where the findings in Section 5.5 support that the teachers suggest being trained to update their skills by their superiors rather than getting monetary assistance. Malaysian educational administrators could use this insight to get more information on better funding allocations on human resource training.

Training should be provided from time to time to make sure that Malaysian teachers are futureproofed. To be constantly updated with the latest skills and knowledge, teachers can provide the best learning experience for their students. Therefore, educational administrators in Malaysia, especially in SLPS, should know what can stimulate teachers' willingness to learn and what prevents them from doing so.

\section{References}

Alea, L. A., Fabrea, M. F., Roldan, R. D. A., \& Farooqi, A. Z. (2020). Teachers' Covid-19 Awareness, Distance Learning Education Experiences and Perceptions towards Institutional Readiness and Challenges. International Journal of Learning, Teaching and Educational Research, 19(6), 127 - 144. https://doi.org/10.26803/ijlter.19.6.8

Alvarez, A. V., Ventura, D. R. M., \& Opiniano, J. H. (2020). Going The Distance: Perceptions Of Teachers In Open And Distance Continuing Professional Development. Globus Journal of Progressive Education, 20(2), 60 - 66. https://www.researchgate.net/publication/345982457_going_the_distance_per ceptions_of_teachers_in_open_and_distance_continuing_professional_develop ment

Badri, M., Alnuaimi, A., Mohaidat, J., Yang, G., \& Al Rashedi, A. (2016). Perception of Teachers' Professional Development Needs, Impacts, and Barriers: The Abu Dhabi Case. SAGE Open, 6(3). https://doi.org/10.1177/2158244016662901

Bin Kamarudin, S., \& Taat, M.S. (2020). Faktor Tingkah Laku Pelajar, Kekangan Masa, Beban Tugas dan Tekanan Kerja Dalam Kalangan Guru [Factors of Students' 
Behaviour, Time Constrain, Work Loads, and Work Stress among Teachers ]. Malaysian Journal of Social Sciences and Humanities (MJSSH) 5(9), 114 - 124. https:// doi.org/10.47405/mjssh.v5i9.481

Bujang, M. A., Omar, E. D., \& Baharum, N. A. (2018). A Review on Sample Size determination for Cronbach Alpha Test: A Simple Guide for Researchers. The Malaysian Journal of Medical Sciences, 25(6), 85-99. https://doi.org/10.21315/mjms2018.25.6.9

Fadzilah, N., Hanafi, M., Fatimah, S., Rahmat, N., Kadar, A., \& Athirah, A. (2021). A Study of Work from Home Motivation among Employees. International Journal of Asian Social Science, 388-398. https://doi.org/10.18488/journal.1.2021.118.388.398.

Hizan, N. S. S., \& Rodzalan, S. A. (2020). Hubungan antara Pengurusan Masa dengan Tekanan Kerja dalam kalangan Guru Sekolah Menengah di Melaka [The Connection Between Time Management and Work Stress among Secondary School Teachers in Melaka]. Research In Management Of Technology And Business. 1(1), 92-103.

Jamil, H. B., Razak, N. A., Raju, R., \& Mohamed, A. R. (2011). Teacher Professional Development in Malaysia : Issues and Challenges. Africa-Asia University Dialogue for Educational Development: report of the International Experience Sharing Seminar 1: Effort toward improving the quality of education. 2: Actual status and issues of teacher professional development (pp. 85-102). Hiroshima University (Japan), Center for the Study of International Cooperation in Education, CICE; University of Cape Coast (Ghana).

Joshi, A., Kale, S., Chandel, S. \& Pal, D. K. (2015). Likert Scale: Explored and Explained. British Journal of Applied Science and Technology, 7(4), 396-403. https://doi.org/10.9734/BJAST/2015/14975

Khan, S. N., \& Kazmi, S. (2020). Pakistani Teachers' Response to COVID-19. Islamabad: Pak Alliance for Maths and Science and Zindagi Trust.

Kincl, T., \& Strach, P. (2018). Born Digital: Is there going to be a new culture of digital native?'. Journal of Global Scholars of Marketing Science. 31, 30-48. https://doi.org/10.1080/21639159.2020.1808811

Konig, J., Jager-Biela, D. J., \& Glutsch, N. (2020). Adapting to Online Teaching during COVID-19 School Closure: Teacher Education and Teacher Competence Effects Among Early Career Teachers in Germany. European Journal of Teacher Education, 43(4), 608-622. https://doi.org/10.1080/02619768.2020.1809650

Malaysia Ministry of Education. (2019, June 12). Pekeliling Perkhidmatan Dasar Latihan Sumber Manusia [Circular of Human Resource Training Policy]. Kementerian Pendidikan Malaysia [Malaysian Ministry of Education]. https://www.moe.gov.my/pekeliling/2621-pekeliling-perkhidmatan-kpm-bil1-tahun-2019-dasar-latihan-sumber-manusia-kementerian-pendidikanmalaysia/file

Malaysia Ministry of Education. (2021, August 2). Panduan Instrument Guru Akademik (PdP Guru) [Teachers' Instrument Instructions (Teaching and Learning)]. Kementerian Pendidikan Malaysia [Malaysian Ministry of Education]. https://eprestasi.moe.gov.my/Borang/Manual2021/3\%20GARIS\%20PANDUA N\%20PBPPP/2\%20PANDUAN\%20INSTRUMEN\%20PBPPP/a\%20INSTRUME $\mathrm{N} \%$ 20PdP.df

Malmqvist, J., Hellberg, K., Mollas, G., Rose, R., \& Shevlin, M. (2019). Conducting the Pilot Study: A Neglected Part of The Research Process? Methodological Findings Supporting the Importance of Piloting in Qualitative Research Studies. International Journal of Qualitative Method, 18. https://doi.org/10.1177/1609406919878341 
Marimuthu, P., \& Vasudevan, H. (2020). The Psychological Impact Of Working from Home During Coronavirus (COVID 19) Pandemic: A Case Study. CnR's International Journal of Social \& Scientific Research, 6(11), 18-29.

Moekwa, B. C. (2020). The Effects Of Continuing Professional Teacher Development On Teachers' Workload In The Gauteng Province. Johannesburg: University Of South Africa.

Muhayimana, T. (2020). Teacher Professional Learning During the Pandemic: Five Critical Areas to Address. Open Journals in Education, 5, 266-279. https://doi.org/10.32674/jsard.v5iS2.2840

Pokhrel, S., \& Chhetri, R. (2021). A Literature Review on Impact of COIVD-19 Pandemic on Teaching and Learning. Higher Education for the Future, 8(1), 133-141. https:// doi.org/10.1177/2347631120983481

Quinn, F., Charteris, J., Adlington, R., Rizk, N., Fletcher, P., \& Parkes, M. (2020). The potential of online technologies in meeting PLD needs of rural teachers. AsiaPacific Journal of Teacher Education. https://doi.org/10.1080/1359866X.2020.1849538

Savvidou, C. (2020). The Impact Of Covid-19 In An Online Teacher Education Course. Cyprus: University of Nicosia.

Shaha, A. I. M., Safri, S. N. A., Thevadas, R., Noordin, N. K., Rahman, A.A., Sekawi, Z., Ideris, A., \& Sultan. M. T. H. (2020). COVID-19 outbreak in Malaysia: Actions taken by the Malaysian government. International Journal of Infectious Diseases, 97, 108-116. https://doi.org/10.1016/j.ijid.2020.05.093

Singh, T.K.R, \& Chan, S. (2014). Teacher Readiness On ICT Integration In TeachingLearning: A Malaysian Case Study. International Journal of Asian Social Science $4(7), 874-885$.

Zakiyuddin. (2019). Teacher Professional Development. Advances in Social Science, Education and Humanities Research. 434, 327-331. https://doi.org/10.2991/assehr.k.200427.066 